\title{
Impact of comorbidity on the risk and cost of hospitalization in HIV- infected patients: real-world data from Abruzzo Region [Corrigendum]
}

\author{
Cammarota S, Citarella A, Manzoli L, Flacco ME, Parruti \\ G. Clinicoecon Outcomes Res. 2018;10:389-398.
}

Page 393, Table 2, CCI score ${ }^{c}$ (vs 0), $\geq 2$ row, the values for the Unadjusted IRR and Adjusted IRR columns are incorrect, the data " 2.32 (1.79-3.01)" should read " $2.87(2.22-3.72)$ " and "2.04 (1.56-2.66)" should read "2.43 (1.86-3.17)".

\section{Publish your work in this journal}

ClinicoEconomics and Outcomes Research is an international, peerreviewed open-access journal focusing on health technology assessment, pharmacoeconomics and outcomes research in the areas of diagnosis, medical devices, and clinical, surgical and pharmacological intervention. The economic impact of health policy and health systems
Dovepress

organization also constitute important areas of coverage. The manuscript management system is completely online and includes a very quick and fair peer-review system, which is all easy to use. Visit http://www.dovepress.com/testimonials.php to read real quotes from published authors. 